\title{
Potential of soil resources of Coconut Research Station, Aliyarnagar, Tamil Nadu, India for agro-technology generation
}

\author{
C. Sudhalakshmi* and R. Kumaraperumal \\ Coconut Research Station, Tamilnadu Agricultural University, Aliyarnagar - 642 101, Tamil Nadu, India
}

(Manuscript Received: 08-06-2020, Revised: 08-09-2020, Accepted: 18-09-2020)

\begin{abstract}
Potential of soil resources of Coconut Research Station, Aliyarnagar of Tamil Nadu Agricultural University and one of the Centers of ICAR-AICRP (Palms), was assessed by soil profile examination and spatial variability mapping. Three soil profiles were examined, one each in A, B and C blocks of the farm horizon wise samples were collected, and fertility parameters were analyzed. Spatial variability of primary nutrients was mapped employing GIS techniques. Soil profile examination revealed the presence of canker nodules in the lower horizons and the depth of the soil was not a constraint for the cultivation of perennial crops. The texture of the soil varied from loamy sand to sandy clay loam. $\mathrm{pH}$ was alkaline and electrical conductivity was less than $2 \mathrm{dSm}^{-1}$. The content of $\mathrm{KMnO}_{4}-\mathrm{N}$ was low, and Olsen $\mathrm{P}, \mathrm{NNNH}_{4} \mathrm{OAc}-\mathrm{K}$ and organic carbon were medium. Land capability class was IIIew and was highly suitable (S1) for coconut, moderately suitable (S2) for cocoa and marginally suitable (S3) for pepper. The soil taxonomic class is fine-loamy mixed, isohyperthermic Fluventic/Typic Haplustepts. Rock outcrops were noticed over 5 per cent of the area. Top soil erosion and seepage problems resulting in temporary water logging are the major fertility constraints associated with this farm. Scrupulous application of organic manures, split application of fertilizers, providing trenches in areas of water logging, etc., are the strategies to overcome the constraints, which are existing in the farm.
\end{abstract}

Keywords: Coconut Research Station, constraints, soil fertility, soil profile, spatial variability

\section{Introduction}

Optimal land, use according to its capability, forms the basis for sustainability whilst exploitation of land beyond the yield potential leads to land degradation. Soils are indispensable resources, but their multipurpose and continuous exploitation have serious impacts on the ecology of a particular region (Gorai et al., 2013). Soils are characterized by a high degree of spatial variability due to the combined effect of physical, chemical and biological processes that operate with different intensities and at different scales (Gooverts, 1998). Today is the era of climate-smart and site-specific farming, in which the nutrient inputs are tailored in accordance with the soil fertility status to meet the crop demand. Variability in soil fertility across farm fields causes spatial variability in crop yields (Rockstrom et al., 1999; Gaston et al., 2001). Information of the soil with respect to its genesis, characteristics, classification and extent of distribution, potentials and problems are imperative for land use planning in a specific area (Mahapatra et al., 2005). For strategic agricultural planning in research stations, the most relevant agricultural issues of a given region have to be identified, and conflicts between the increase in productivity and degradation of natural resources addressed.

Assessing soil variability, irrigation water quality and profile exploration in research institutes dealing with principal crops is crucial for the correlation of data generated from various field experiments, to understand the existing soil fertility

*Corresponding Author: soilsudha@yahoo.co.in 
constraints, to bring out its interaction with the environment and to extrapolate the obtained results to the farmers of the region for effective land use. Coconut Research Station at Aliyarnagar is one of the crop-oriented research stations of Tamil Nadu Agricultural University located in the Western Zone of Tamil Nadu and a prominent research centre of the ICAR - All India Co-coordinated Research Project on Palms. The station is vested with the regional and national responsibilities of evolving new varieties of coconut, assessing the suitability of crops to adapt to the cropping pattern of Western Zone of Tamil Nadu and to develop integrated pest and disease management strategies for coconut and coconut-based intercrops. Hence, the present study was undertaken to examine the soil profiles of various blocks of the farm in which coconut and coconut-based intercrops are cultivated, characterize the horizons, assess the quality of irrigation water to devise comprehensive land use plan and to develop agricultural technologies for maximizing farm income.

\section{Materials and methods}

Coconut Research Station is located near Western Ghats $\left(10^{\circ} 29^{\prime} 499^{\prime \prime} \mathrm{N}\right.$ and $\left.76^{\circ} 58^{\prime} 821^{\prime \prime} \mathrm{E}\right)$ in the Western zone of Coimbatore district of Tamil $\mathrm{Nadu}$, at an elevation of $260 \mathrm{~m}$ above MSL with undulating topography. The average annual rainfall of the tract is $802 \mathrm{~mm}$, of which nearly $300 \mathrm{~mm}$ is received during South-West monsoon, $333 \mathrm{~mm}$ during North-East monsoon and $169 \mathrm{~mm}$ during summer. The station owns 22 hectares of land, of which nearly 18.8 hectares are under cultivation. It is divided into three blocks viz., A, B and C for ease of management. Parambikulam Aliyar canal (supplemented by one open well) serve as the source of irrigation. The soil type of the station is sandy clay loam (Typic/Fluventic Haplustepts). The major and predominant geological formations of Aliyar are of granite gneiss, biotite gneiss and charnockite in general. Massive gneissic outcrops are observed along the Aliyar river. The foliation trend is North-East to South-West with a southeasterly dip. The thickness of the weathered zone ranges from 3 to 4 meters in general. The fissured hard rock formations are of the peninsular gneissic complex of Archean age.
Three master profiles were examined (Bhattacharya et al., 2009) one each in the three blocks, soil samples of each horizon of representative pedons were collected, processed and analyzed for important physico-chemical properties employing standard procedures (Sarma et al., 1987). Surface $(0-15 \mathrm{~cm})$ and sub-surface $(15-30 \mathrm{~cm})$ samples were collected from all the 43 fields of the farm. Soil fertility parameters viz., $\mathrm{pH}$, electrical conductivity, $\mathrm{KMnO}_{4}-\mathrm{N}$, Olsen $\mathrm{P}$ and $\mathrm{NNNH}_{4} \mathrm{OAc}-\mathrm{K}$ were analysed in the soil samples as per the procedures outlined by Black (1965). The soil map was overlaid over Quick Bird Satellite Imagery and digitized (Fig. 1). A database file consisting of data for $\mathrm{X}$ and $\mathrm{Y}$ coordinates was created in Microsoft Excel. A shape file showing the sampling locations was created in Arc GIS software. The database file was joined to the point data. Thematic maps on available nutrient status $(\mathrm{N}, \mathrm{P}$ and $\mathrm{K})$ were generated

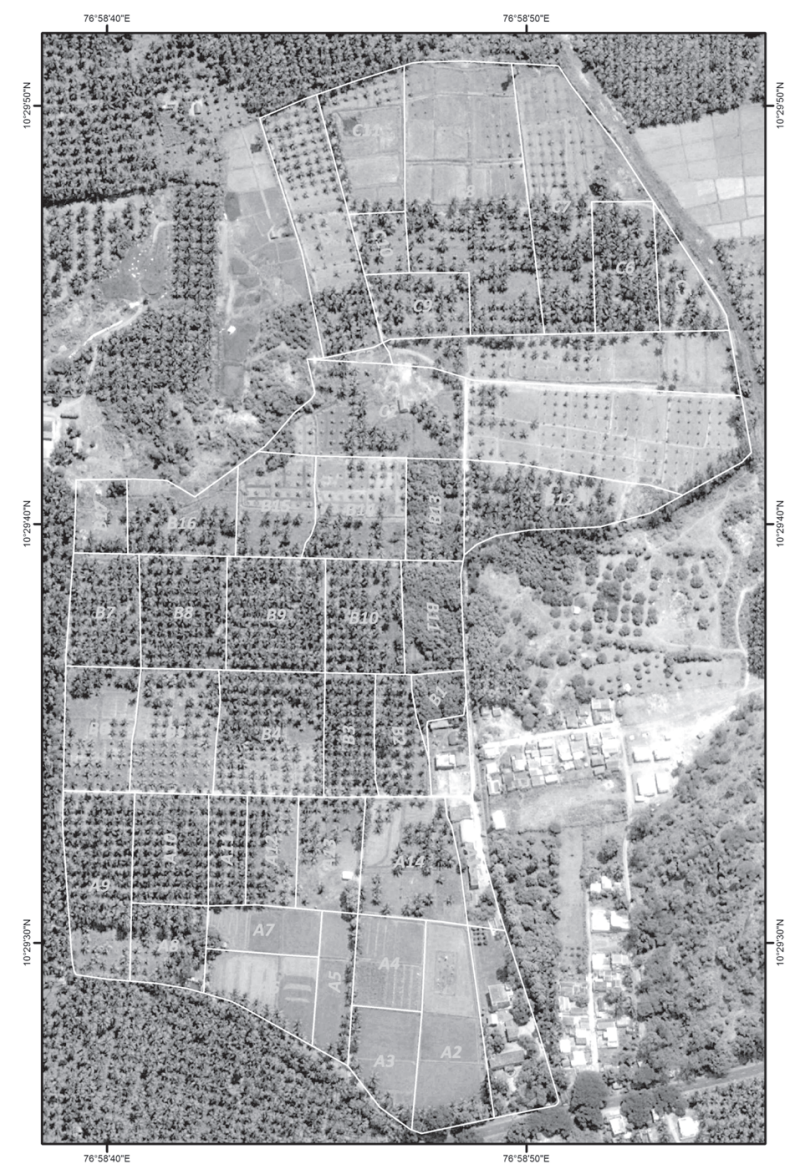

Fig. 1. Farm map overlaid over Quick Bird Satellite Imagery 
by categorizing the fertility status as 'low', 'medium' and 'high' by kriging.

\section{Results and discussion}

\section{Morphological characteristics of soils}

The morphological characteristics of the horizons of diverse pedons are presented in Tables 1,2 and 3. The horizonation of the soil profiles with hue, value and chroma is depicted in Figure 2.

Pedon 1 explored in field A5 of A block is brown to dark brown, sandy loam to sandy clay loam in texture, sub-angular blocky in structure; slightly hard, slightly firm exhibiting strong effervescence on testing with $\mathrm{HCl}$. The depth is $150 \mathrm{~cm}$, and the parent material is weathered gneiss. Research trial on the comparative evaluation of Niu Leka Green Dwarf, Chowghat Orange Dwarf and Malayan Green Dwarf varieties of coconut is undertaken in this field. Pedon 2 excavated in field B8 is brown to dark brown, loamy sand in the surface and sandy clay loam in the subsurface, non-sticky and non-plastic in the surface horizons, moderately sticky and plastic in the subsurface with brisk effervescence on testing with dilute $\mathrm{HCl}$. The land use of the field in which the pedon was excavated is multiple cropping with cocoa clones CCRP 1-7, coconut and pepper. Pedon 3 was opened in field $\mathrm{C} 8$ in which exotic breeds of coconut is being maintained. The texture varies from sandy clay loam to sandy clay and exhibits strong to violent effervescence throughout the profile.

\section{Analysis of horizon wise soil samples}

Physical and chemical properties in the horizons of soil profiles are depicted hereunder.

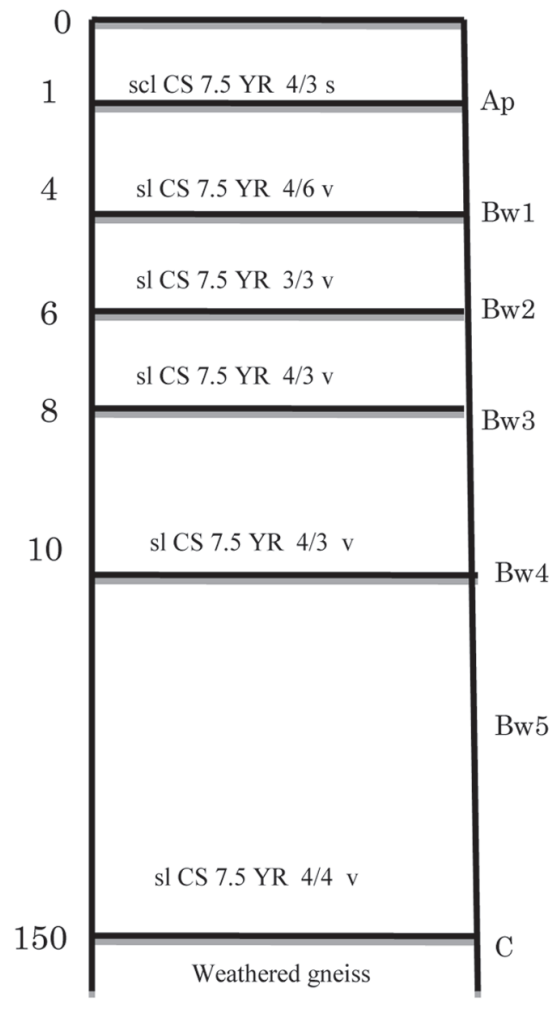

Coarse-loamy mixed, calcareous isohyperthermic, Fluventic Haplustepts

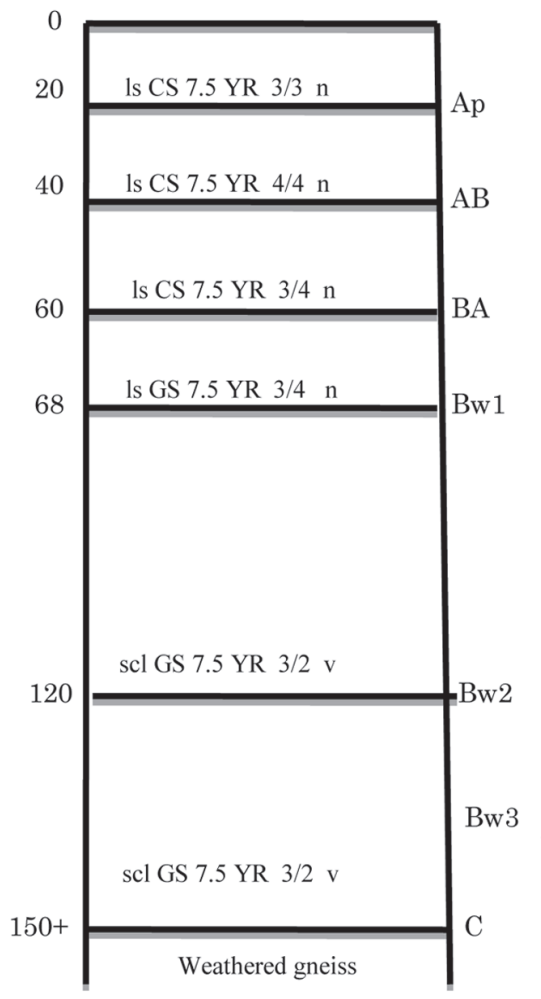

Coarse-loamy, mixed, calcareous isohyperthermic, Typic Haplustepts

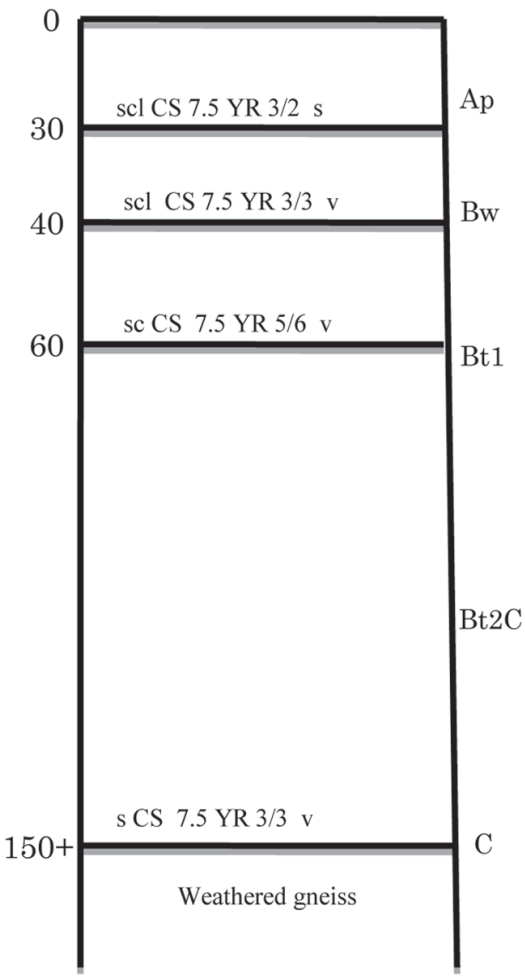

Fine-loamy, mixed, calcareous isohyperthermic, Typic Haplustalfs

Fig. 2. Horizonation of the soil profiles 
Table 1. Description of the soil profile 1 (Field A5)

Taxonomic Class: Coarse-loamy mixed, calcareous, isohyperthermic, Fluventic Haplustepts

Land Use: Coconut cultivars: Niu Leka Green Dwarf, Chowghat Orange Dwarf and Malayan Green Dwarf

\begin{tabular}{|c|c|c|}
\hline Horizon & Depth & Description \\
\hline Ap & $0-18 \mathrm{~cm}$ & $\begin{array}{l}\text { Brown ( } 7.5 \text { YR 4/3), sandy clay loam; moderate medium sub-angular blocky; slightly hard, } \\
\text { slightly firm, moderately sticky and moderately plastic; very fine, common roots; common } \\
\text { fine, very fine pores; strong effervescence; strongly alkaline ( } \mathrm{pH} 8.84) \text { and clear smooth } \\
\text { boundary. }\end{array}$ \\
\hline Bw1 & $18-44 \mathrm{~cm}$ & $\begin{array}{l}\text { Brown ( } 7.5 \text { YR 4/6), sandy loam; weak medium sub-angular blocky; slightly hard, slightly } \\
\text { firm, slightly sticky and slightly plastic; fine, common roots; common fine, very fine pores; } \\
\text { violent effervescence, strongly alkaline ( } \mathrm{pH} 8.57 \text { ) and clear smooth boundary. }\end{array}$ \\
\hline Bw2 & $44-65 \mathrm{~cm}$ & $\begin{array}{l}\text { Dark brown (7.5YR 3/3), sandy loam; weak medium sub-angular blocky; slightly hard, slightly } \\
\text { firm, slightly sticky and slightly plastic; fine, common roots; many fine, very fine pores; violent } \\
\text { effervescence, strongly alkaline ( } \mathrm{pH} 8.50 \text { ) and clear smooth boundary. }\end{array}$ \\
\hline Bw3 & $65-75 \mathrm{~cm}$ & $\begin{array}{l}\text { Brown (7.5YR 4/3), sandy loam; weak medium sub-angular blocky; slightly hard, slightly } \\
\text { firm, slightly sticky and slightly plastic; fine, many roots; common fine, very fine pores; violent } \\
\text { effervescence; strongly alkaline ( } \mathrm{pH} 8.75 \text { ) and clear smooth boundary. }\end{array}$ \\
\hline Bw4 & $75-85 \mathrm{~cm}$ & $\begin{array}{l}\text { Brown ( } 7.5 \text { YR 4/3), sandy loam; weak medium sub-angular blocky; slightly hard, slightly } \\
\text { firm, slightly sticky and slightly plastic; fine, many roots; common fine, very fine pores; clear } \\
\text { smooth boundary; violent effervescence, strongly alkaline ( } \mathrm{pH} 8.67 \text { ) and clear smooth boundary. }\end{array}$ \\
\hline Bw5 & $85-108 \mathrm{~cm}$ & $\begin{array}{l}\text { Brown ( } 7.5 \text { YR 4/4), sandy loam; weak medium sub-angular blocky; slightly hard, slightly } \\
\text { firm, slightly sticky and slightly plastic; fine, few roots; common fine, very fine pores; clear } \\
\text { smooth boundary; violent effervescence; strongly alkaline ( } \mathrm{pH} \mathrm{8.67)} \mathrm{and} \mathrm{clear} \mathrm{smooth} \mathrm{boundary}\end{array}$ \\
\hline $\mathrm{Cr}$ & $108-150 \mathrm{~cm}$ & Weathered gneiss \\
\hline
\end{tabular}

Table 2. Description of the soil profile 2 (Field B8)

Taxonomic Class: Coarse-loamy, mixed, calcareous. isohyperthermic Typic Haplustepts

Land Use: Multi-storeyed cropping with coconut, cocoa and pepper.

\begin{tabular}{|c|c|c|}
\hline Horizon & Depth & Description \\
\hline$\overline{A p}$ & $0-20 \mathrm{~cm}$ & $\begin{array}{l}\text { Dark brown ( } 7.5 \text { YR 3/3), loamy sand; granular, loose, friable, non- sticky and non-plastic; } \\
\text { medium, many roots; common fine and very fine pores; slightly alkaline ( } \mathrm{pH} 7.63) \text { and clear } \\
\text { smooth boundary. }\end{array}$ \\
\hline $\mathrm{AB}$ & $20-40 \mathrm{~cm}$ & $\begin{array}{l}\text { Brown }(7.5 \text { YR } 4 / 4) \text {, loamy sand; granular, loose, friable, non-sticky and non-plastic; medium, } \\
\text { many roots; common fine and very fine pores; clear smooth boundary; slightly alkaline (pH } \\
7.42 \text { ) and clear smooth boundary. }\end{array}$ \\
\hline $\mathrm{BA}$ & $40-60 \mathrm{~cm}$ & $\begin{array}{l}\text { Dark brown ( } 7.5 \text { YR } 3 / 4) \text {, loamy sand; granular, loose, friable, non- sticky and non-plastic; } \\
\text { fine, many roots; common fine and very fine pores; moderately alkaline }(\mathrm{pH} 8.11) \text { and clear } \\
\text { smooth boundary. }\end{array}$ \\
\hline Bw1 & $60-88 \mathrm{~cm}$ & $\begin{array}{l}\text { Dark brown ( } 7.5 \text { YR } 3 / 4) \text {, loamy sand; granular, loose, friable, non- sticky and non-plastic; } \\
\text { fine, few roots; common fine pores; moderately alkaline }(\mathrm{pH} 8.34) \text { and gradual smooth boundary. }\end{array}$ \\
\hline
\end{tabular}


Potential of soil resources for agro-technology

\begin{tabular}{|c|c|c|}
\hline Bw2 & $88-120 \mathrm{~cm}$ & $\begin{array}{l}\text { Dark brown ( } 7.5 \text { YR } 3 / 2) \text {, sandy clay loam; moderate, medium sub- angular blocky; slightly } \\
\text { hard, slightly firm, moderately sticky and moderately plastic; fine, few roots; few fine and very } \\
\text { fine pores; strongly alkaline ( } \mathrm{pH} 8.61 \text { ) and gradual smooth boundary. }\end{array}$ \\
\hline Bw3 & $120-150 \mathrm{~cm}$ & $\begin{array}{l}\text { Dark brown ( } 7.5 \text { YR } 3 / 2) \text {, sandy clay loam; moderate, medium sub- angular blocky; slightly } \\
\text { hard, slightly firm, moderately sticky and moderately plastic; fine, many roots; common fine } \\
\text { and very fine pores; gradual smooth boundary; violent effervescence; strongly alkaline ( } \mathrm{pH} \\
8.52) \text {. }\end{array}$ \\
\hline $\mathrm{Cr}$ & $150+$ & Weathered gneiss \\
\hline
\end{tabular}

Table 3. Description of the soil profile 3 (Field C8)

Taxonomic Class: Fine- loamy, mixed, calcareous isohyperthermic Typic Haplustalfs

Land Use: Coconut - Exotic varieties

\begin{tabular}{|c|c|c|}
\hline Horizon & Depth & Description \\
\hline Ap & $0-30 \mathrm{~cm}$ & $\begin{array}{l}\text { Dark brown (7.5YR 3/2), sandy clay loam; moderate medium sub- angular blocky; slightly } \\
\text { hard, slightly firm, moderately sticky and moderately plastic; very fine few roots; few fine and } \\
\text { very fine pores; clear smooth boundary; strong effervescence; moderately alkaline (pH 8.31) } \\
\text { and clear smooth boundary. }\end{array}$ \\
\hline $\mathrm{Bw}$ & $30-40 \mathrm{~cm}$ & $\begin{array}{l}\text { Dark brown ( } 7.5 \text { YR } 3 / 3) \text {, sandy clay loam; moderate medium sub- angular blocky; slightly } \\
\text { hard, slightly firm, moderately sticky and moderately plastic; fine few roots; few fine and very } \\
\text { fine pores; violent effervescence; strongly alkaline ( } \mathrm{pH} 8.53 \text { ) and gradual smooth boundary. }\end{array}$ \\
\hline Bt1 & $40-60 \mathrm{~cm}$ & $\begin{array}{l}\text { Dark brown (7.5YR 4/4), sandy clay; moderate medium sub-angular blocky; slightly hard, } \\
\text { slightly firm, moderately sticky and moderately plastic; fine few roots; few fine pores; patchy } \\
\text { thin clay skins; violent effervescence; moderately alkaline ( } \mathrm{pH} 8.43 \text { ) and gradual smooth } \\
\text { boundary. }\end{array}$ \\
\hline $\mathrm{Bt} 2 \mathrm{C}$ & $60-150 \mathrm{~cm}$ & $\begin{array}{l}\text { Dark brown ( } 7.5 \text { YR 3/3), gravelly sand; moderate medium sub-angular blocky; slightly hard, } \\
\text { slightly firm, moderately sticky and moderately plastic; few fine roots; few fine and very fine } \\
\text { pores; patchy thin clay skins; violent effervescence; strongly alkaline (pH 8.65). }\end{array}$ \\
\hline $\mathrm{Cr}$ & $150+$ & Weathered gneiss \\
\hline
\end{tabular}

\section{Physical properties}

Bulk density of the horizons varied from 1.34 to $1.74 \mathrm{Mg} \mathrm{m}^{-3}$ across different profiles. Bulk density was remarkably less in the clay dominant horizons and was higher in the sandy textured layers. In the A block profile, the surface horizon had lower bulk density compared to the sub-surface horizons, which may be attributed to compaction of the soil because of the recurrent use of machineries. In B block profile, bulk density was less in Bw2 and Bw3 horizons compared to the upper layers. In the profile of $\mathrm{C}$ block, bulk density was higher in Bt2C compared to other horizons. Particle density ranged from 2.31 to $2.76 \mathrm{Mg} \mathrm{m}^{-3}$ and the porosity from 24.7 to 51.4 per cent across different horizons. Coarse fragments on volume basis ranged from 1.8 to 19.0 per cent in different horizons (Table 4). Percentage of coarse fragments in the soil was less in the cocoa intercropped fields of B block and was the highest in $\mathrm{C}$ block of the farm wherein exotic varieties of coconut is cultivated.

\section{Electrochemical properties}

The $\mathrm{pH}$ of the soil samples collected in the soil profile of A block was strongly alkaline, and an inconsistent trend was observed with respect to the variation in $\mathrm{pH}$ among the horizons. In the soil 
Table 4. Physical properties of the horizon samples of soil profiles

\begin{tabular}{|c|c|c|c|c|c|c|c|c|}
\hline $\begin{array}{l}\text { Sl. } \\
\text { No. }\end{array}$ & $\begin{array}{l}\text { Horizon with } \\
\text { depth range }\end{array}$ & $\begin{array}{c}\text { Bulk } \\
\text { density } \\
\left(\mathrm{Mg} \mathrm{m}^{-3}\right)\end{array}$ & $\begin{array}{c}\text { Particle } \\
\text { density } \\
\left(\mathrm{Mg} \mathrm{m}^{-3}\right)\end{array}$ & $\begin{array}{c}\text { Porosity } \\
(\%)\end{array}$ & $\begin{array}{l}\text { Sand } \\
(\%)\end{array}$ & $\begin{array}{l}\text { Silt } \\
(\%)\end{array}$ & $\begin{array}{l}\text { Clay } \\
(\%)\end{array}$ & $\begin{array}{c}\text { Coarse fragments } \\
\text { on a volume } \\
\text { basis }(\%) \\
\end{array}$ \\
\hline & Profile - A Block & & & & & & & \\
\hline 1. & Ap $(0-18 \mathrm{~cm})$ & 1.44 & 2.52 & 38.9 & 51 & 17 & 24 & 5.2 \\
\hline 2. & Bw1 $(18-44 \mathrm{~cm})$ & 1.60 & 2.43 & 34.2 & 65 & 12 & 09 & 8.8 \\
\hline 3. & Bw2 (44-65 cm) & 1.65 & 2.43 & 32.1 & 62 & 10 & 11 & 10.3 \\
\hline 4. & Bw3 $(65-75 \mathrm{~cm})$ & 1.55 & 2.36 & 34.3 & 58 & 11 & 09 & 14.2 \\
\hline 5. & Bw4 $(75-85 \mathrm{~cm})$ & 1.60 & 2.73 & 41.4 & 60 & 12 & 10 & 11.3 \\
\hline \multirow[t]{2}{*}{6.} & Bw5 (85-108 cm) & 1.55 & 2.73 & 43.2 & 59 & 09 & 11 & 13.5 \\
\hline & Profile - B Block & & & & & & & \\
\hline 7. & Ap $(0-20 \mathrm{~cm})$ & 1.65 & 2.56 & 35.5 & 75 & 9 & 6 & 6.1 \\
\hline 8. & AB $(20-40 \mathrm{~cm})$ & 1.65 & 2.62 & 37.0 & 80 & 8 & 7 & 3.0 \\
\hline 9. & $\mathrm{BA}(40-60 \mathrm{~cm})$ & 1.65 & 2.58 & 36.0 & 77 & 9 & 8 & 3.6 \\
\hline 10 & Bw1 $(60-88 \mathrm{~cm})$ & 1.70 & 2.61 & 34.9 & 81 & 10 & 6 & 1.8 \\
\hline 11. & Bw2 $(88-120 \mathrm{~cm})$ & 1.42 & 2.56 & 36.7 & 48 & 15 & 28 & 5.6 \\
\hline \multirow[t]{2}{*}{12.} & Bw3 (120-150 cm) & 1.48 & 2.64 & 38.6 & 50 & 18 & 24 & 4.9 \\
\hline & Profile - C Block & & & & & & & \\
\hline 13. & Ap $(0-30 \mathrm{~cm})$ & 1.48 & 2.61 & 41.0 & 48 & 17 & 15 & 13.0 \\
\hline 14. & Bw $(30-40 \mathrm{~cm})$ & 1.60 & 2.59 & 38.2 & 50 & 18 & 16 & 10.0 \\
\hline 15. & Bt1 $(40-60 \mathrm{~cm})$ & 1.34 & 2.76 & 51.4 & 42 & 17 & 30 & 8.2 \\
\hline 16. & $\mathrm{Bt} 2 \mathrm{C}(60-150 \mathrm{~cm})$ & 1.74 & 2.31 & 24.7 & 50 & 12 & 5 & \\
\hline
\end{tabular}

profile of B block, $\mathrm{pH}$ of the horizons 1 and 2 was neutral whilst the rest were slightly alkaline. In ' $\mathrm{C}$ ' block, $\mathrm{pH}$ of all the horizons hovered around 8.3-8.6. The increased $\mathrm{pH}$ in specific horizons may be attributed to the calcareous nature of the soils in certain depths. This was further confirmed by effervescence with $\mathrm{HCl}$. Electrical conductivity was $<2 \mathrm{dS} \mathrm{m}^{-1}$ irrespective of the depth of sampling. The results are in close compliance with Selvamani and Duraisami (2014), who reported 95 per cent of the soil samples of Coimbatore district are non- saline in nature. The inconsistent trend in variation of EC along the horizons restricts drawing a valid conclusion. The cation exchange capacity of the soil was higher in the horizons with clay texture and was the least in the horizon with sandy texture (Table 5). The results are in close compliance with Yunan et al. (2018) who established a positive correlation between the contents of clay, silt and organic matter and negative correlation with sand. Per cent base saturation was high in the top horizons of $\mathrm{C}$ block and was the lowest in $\mathrm{Bt} 2 \mathrm{C}$ horizon of $\mathrm{C}$ block.

\section{Primary nutrients}

$\mathrm{KMnO}_{4}-\mathrm{N}$ content of all the soil samples of the horizons was low in status, and a gentle gradation was observed with increasing depth of the profile. The surface horizons recorded comparatively higher $\mathrm{KMnO}_{4}-\mathrm{N}$ content than the sub-surface horizons. The results are in close compliance with Sudhalakshmi et al. (2017), who reported 92 per cent of the surface soils of the farm to have the low status of $\mathrm{KMnO}_{4}-\mathrm{N}$. Olsen-P content was low to medium irrespective of the horizonation. The very low content of phosphorus in the horizons of C block may be attributed to the fixation of $\mathrm{P}$ as calcium phosphate. The status of $\mathrm{NNNH}_{4} \mathrm{OAc}-\mathrm{K}$ content was low to medium across the horizons, and exchangeable sodium content was beyond the threat for developing any chemical constraint (Table 6). 
Potential of soil resources for agro-technology

Table 5. Electrochemical properties of the horizon samples of soil profiles

\begin{tabular}{|c|c|c|c|c|c|}
\hline $\begin{array}{l}\text { SI. } \\
\text { No. }\end{array}$ & $\begin{array}{l}\text { Horizon with } \\
\text { depth range }\end{array}$ & pH & 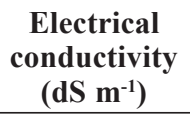 & $\begin{array}{c}\text { Cation exchange } \\
\text { capacity } \\
\left(\mathrm{cmol}(+) \mathrm{kg}^{-1} \text { soil }\right) \\
\end{array}$ & $\begin{array}{c}\text { Base } \\
\text { saturation } \\
(\%) \\
\end{array}$ \\
\hline & Profile - A Block & & & & \\
\hline 1. & Ap $(0-18 \mathrm{~cm})$ & 8.84 & 0.13 & 12.2 & 72.2 \\
\hline 2. & Bw1 $(18-44 \mathrm{~cm})$ & 8.57 & 0.09 & 10.8 & 65.6 \\
\hline 3. & Bw2 (44-65 cm) & 8.50 & 0.09 & 10.8 & 65.6 \\
\hline 4. & Bw3 $(65-75 \mathrm{~cm})$ & 8.75 & 0.11 & 11.8 & 68.4 \\
\hline 5. & Bw4 $(75-85 \mathrm{~cm})$ & 8.67 & 0.07 & 10.4 & 70.4 \\
\hline \multirow[t]{2}{*}{6.} & Bw5 $(85-108 \mathrm{~cm})$ & 8.67 & 0.07 & 10.4 & 70.4 \\
\hline & Profile - B Block & & & & \\
\hline 7. & Ap $(0-20 \mathrm{~cm})$ & 7.63 & 0.08 & 7.8 & 60.8 \\
\hline 8. & AB $(20-40 \mathrm{~cm})$ & 7.42 & 0.04 & 8.2 & 56.8 \\
\hline 9. & $\mathrm{BA}(40-60 \mathrm{~cm})$ & 8.11 & 0.05 & 9.1 & 57.8 \\
\hline 10. & Bw1 $(60-88 \mathrm{~cm})$ & 8.34 & 0.07 & 8.6 & 57.8 \\
\hline 11. & Bw2 $(88-120 \mathrm{~cm})$ & 8.61 & 0.08 & 11.9 & 69.6 \\
\hline \multirow[t]{2}{*}{12.} & Bw3 $(120-150 \mathrm{~cm})$ & 8.52 & 0.10 & 10.6 & 66.8 \\
\hline & Profile - C Block & & & & \\
\hline 13. & Ap $(0-30 \mathrm{~cm})$ & 8.31 & 0.09 & 12.8 & 79.2 \\
\hline 14. & $\mathrm{Bw}(30-40 \mathrm{~cm})$ & 8.53 & 0.10 & 12.8 & 76.4 \\
\hline 15. & Bt1 $(40-60 \mathrm{~cm})$ & 8.43 & 0.11 & 13.2 & 74.2 \\
\hline 16. & $\mathrm{Bt} 2 \mathrm{C}(60-150 \mathrm{~cm})$ & 8.65 & 0.10 & 3.4 & 50.2 \\
\hline
\end{tabular}

Table 6. $\mathrm{KMnO}_{4}-\mathrm{N}$, Olsen-P, $\mathrm{NNNH}_{4} \mathrm{OAc}-\mathrm{K}$ and exchangeable $\mathrm{Na}\left(\mathrm{kg} \mathrm{ha}^{-1}\right)$ in the horizon samples of soil profiles

\begin{tabular}{|c|c|c|c|c|c|}
\hline SI. & & $\mathrm{KMnO}_{4}-\mathrm{N}$ & Olsen-P & $\mathrm{NNNH}_{4} \mathrm{OAc}-\mathrm{K}$ & Exch. $\mathrm{Na}$ \\
\hline No. & depth range & & & & \\
\hline 1. & Ap $(0-18 \mathrm{~cm})$ & 232.1 & 11.6 & 198.0 & 73.7 \\
\hline 2. & Bw1 $(18-44 \mathrm{~cm})$ & 178.8 & 8.1 & 107.8 & 73.7 \\
\hline 3. & Bw2 (44-65 cm) & 112.9 & 15.8 & 106.7 & 73.7 \\
\hline 4. & Bw3 $(65-75 \mathrm{~cm})$ & 97.2 & 15.5 & 105.6 & 73.7 \\
\hline 5. & Bw4 $(75-85 \mathrm{~cm})$ & 106.6 & 9.5 & 106.7 & 73.7 \\
\hline 6. & Bw5 $(85-108 \mathrm{~cm})$ & 97.2 & 9.1 & 107.8 & 73.7 \\
\hline 7. & Ap $(0-20 \mathrm{~cm})$ & 244.6 & 17.8 & 107.8 & 73.7 \\
\hline 8. & $\mathrm{AB}(20-40 \mathrm{~cm})$ & 188.2 & 14.8 & 130.9 & 75.9 \\
\hline 9. & BA $(40-60 \mathrm{~cm})$ & 125.4 & 7.6 & 125.4 & 73.7 \\
\hline 10. & Bw1 $(60-88 \mathrm{~cm})$ & 144.3 & 17.5 & 128.7 & 73.7 \\
\hline 11. & $\mathrm{Bw} 2(88-120 \mathrm{~cm})$ & 166.2 & 13.1 & 113.3 & 73.7 \\
\hline 12. & Bw3 $(120-150 \mathrm{~cm})$ & 163.1 & 8.4 & 107.8 & 73.7 \\
\hline 13. & Ap $(0-30 \mathrm{~cm})$ & 250.9 & 16.1 & 107.8 & 73.7 \\
\hline 14. & $\mathrm{Bw}(30-40 \mathrm{~cm})$ & 250.9 & 5.9 & 105.6 & 78.1 \\
\hline 15. & Bt1 $(40-60 \mathrm{~cm})$ & 244.6 & 9.1 & 110.0 & 73.7 \\
\hline 16. & $\mathrm{Bt} 2 \mathrm{C}(60-150 \mathrm{~cm})$ & 241.5 & 4.8 & 107.8 & 73.7 \\
\hline
\end{tabular}


Table 7. Organic carbon (\%), exchangeable Ca, $\mathrm{Mg}$ (meq per $100 \mathrm{~g}$ ) and available sulphur (ppm) in the horizon samples of soil profiles

\begin{tabular}{|c|c|c|c|c|c|}
\hline $\begin{array}{l}\text { Sl. } \\
\text { No. }\end{array}$ & $\begin{array}{l}\text { Horizon with } \\
\text { depth range }\end{array}$ & $\begin{array}{c}\text { Organic carbon } \\
(\%) \\
\end{array}$ & $\frac{\text { Exch. Ca }}{\text { (mec }}$ & $\frac{\text { Exch. Mg }}{0 \text { g) }}$ & $\begin{array}{c}\text { Available } S \\
\text { (ppm) }\end{array}$ \\
\hline 1. & Ap $(0-18 \mathrm{~cm})$ & 0.63 & 8.1 & 7.4 & 15.6 \\
\hline 2. & Bw1 (18- $44 \mathrm{~cm})$ & 0.59 & 9.0 & 10.1 & 13.4 \\
\hline 3. & Bw2 (44-65 cm) & 0.45 & 4.5 & 10.9 & 12.7 \\
\hline 4. & Bw3 $(65-75 \mathrm{~cm})$ & 0.38 & 4.5 & 12.9 & 12.3 \\
\hline 5. & $\mathrm{Bw} 4(75-85 \mathrm{~cm})$ & 0.69 & 5.0 & 13.8 & 14.2 \\
\hline 6. & Bw5 $(85-108 \mathrm{~cm})$ & 0.55 & 4.3 & 8.7 & 13.9 \\
\hline 7. & Ap $(0-20 \mathrm{~cm})$ & 0.34 & 4.4 & 2.8 & 12.8 \\
\hline 8. & $\mathrm{AB}(20-40 \mathrm{~cm})$ & 0.34 & 2.1 & 3.5 & 12.6 \\
\hline 9. & $\mathrm{BA}(40-60 \mathrm{~cm})$ & 0.27 & 2.1 & 5.1 & 11.8 \\
\hline 10 & Bw1 (60-88 cm) & 0.22 & 2.0 & 7.1 & 12.7 \\
\hline 11 & Bw2 $(88-120 \mathrm{~cm})$ & 0.25 & 2.8 & 11.8 & 12.4 \\
\hline 12. & Bw3 $(120-150 \mathrm{~cm})$ & 0.37 & 5.2 & 12.5 & 11.9 \\
\hline 13. & $A p(0-30 \mathrm{~cm})$ & 0.22 & 3.9 & 10.1 & 12.7 \\
\hline 14. & $\mathrm{Bw}(30-40 \mathrm{~cm})$ & 0.17 & 5.1 & 12.1 & 13.4 \\
\hline 15 & Bt1 (40-60 cm) & 0.15 & 3.7 & 14.7 & 14.1 \\
\hline 16. & $\mathrm{Bt} 2 \mathrm{C}(60-150 \mathrm{~cm})$ & 0.09 & 10.5 & 8.3 & 13.9 \\
\hline
\end{tabular}

\section{Organic carbon and secondary nutrients}

Irrespective of the horizons, exchangeable calcium, magnesium and available sulphur were sufficient. This may be due to the calcareous nature of the soil, magnesium bicarbonate rich irrigation water and addition of sulphur through various sources of fertilizers like SSP, gypsum and micronutrient fertilizers. Organic carbon content was low to medium except for the surface horizon of A block profile in which a high content was observed which may be attributed to the incorporation of groundnut haulms over years of cultivation (Table 7).

\section{Water-soluble chloride (meq per $\mathrm{kg}$ ), free $\mathrm{CaCO}_{3}(\%)$ and hot water soluble boron (ppm)}

The water-soluble chloride content of all the samples was well within the non-hazardous limits, which may be due to the sandy texture of the soil. All the soil samples except those collected from C block were moderately calcareous. Hot watersoluble B was sufficient in the surface horizons but was deficient in the sub-surface horizons witnessed by calcareous patches (Table 8). A plethora of
Table 8. Water-soluble chloride (meq kg-1), free $\mathrm{CaCO}_{3}(\%)$ and hot water soluble boron (ppm) contents in the horizon samples of soil profiles

\begin{tabular}{llccc}
\hline $\begin{array}{l}\text { Sl. } \\
\text { No. }\end{array}$ depth range & $\begin{array}{c}\text { Water-soluble } \\
\text { chloride } \\
\left(\mathbf{m e q} \mathbf{~ k g}^{-1}\right)\end{array}$ & $\begin{array}{c}\text { Free } \\
\text { CaCO } \\
(\%)\end{array}$ & $\begin{array}{c}\text { Hot water- } \\
\text { soluble B } \\
(\mathbf{p p m})\end{array}$ \\
\hline 1. & Ap $(0-18 \mathrm{~cm})$ & 4.0 & 3.06 & 0.5120 \\
2. & Bw1 $(18-44 \mathrm{~cm})$ & 2.0 & 3.10 & 0.4070 \\
3. & Bw2 $(44-65 \mathrm{~cm})$ & 3.0 & 2.94 & 0.3090 \\
4. & Bw3 $(65-75 \mathrm{~cm})$ & 3.0 & 3.04 & 0.4045 \\
5. & Bw4 $(75-85 \mathrm{~cm})$ & 8.0 & 2.98 & 0.9045 \\
6. & Bw5 $(85-108 \mathrm{~cm})$ & 8.0 & 2.70 & 0.4070 \\
7. & Ap $(0-20 \mathrm{~cm})$ & 7.5 & 1.75 & 0.5215 \\
8. & AB $(20-40 \mathrm{~cm})$ & 7.0 & 1.55 & 0.5090 \\
9. & BA $(40-60 \mathrm{~cm})$ & 6.5 & 1.56 & 0.2260 \\
10. & Bw1 $(60-88 \mathrm{~cm})$ & 6.0 & 1.65 & 0.3165 \\
11. & Bw2 $(88-120 \mathrm{~cm})$ & 7.0 & 3.06 & 0.2285 \\
12. & Bw3 $(120-150 \mathrm{~cm})$ & 8.0 & 3.10 & 0.3120 \\
13. & Ap $(0-30 \mathrm{~cm})$ & 4.0 & 2.93 & 0.3045 \\
14. & Bw $(30-40 \mathrm{~cm})$ & 5.5 & 3.11 & 0.2020 \\
15. & Bt1 $(40-60 \mathrm{~cm})$ & 5.5 & 3.10 & 0.2265 \\
16. & Bt2C $(60-150 \mathrm{~cm})$ & 9.0 & 3.10 & 0.2070 \\
\hline
\end{tabular}


Table 8. Water-soluble chloride (meq $\left.\mathrm{kg}^{-1}\right)$, free $\mathrm{CaCO}_{3}(\%)$ and hot water soluble boron (ppm) contents in the horizon samples of soil profiles

\begin{tabular}{llccc}
\hline $\begin{array}{l}\text { Sl. } \\
\text { No. }\end{array}$ depth range & $\begin{array}{c}\text { Water-soluble } \\
\text { chloride } \\
\text { (meq kg-1 }\end{array}$ & $\begin{array}{c}\text { Free } \\
\text { CaCO } \\
\text { (\%) }\end{array}$ & $\begin{array}{c}\text { Hot water- } \\
\text { soluble B } \\
\text { (ppm) }\end{array}$ \\
\hline 1. & Ap $(0-18 \mathrm{~cm})$ & 4.0 & 3.06 & 0.5120 \\
2. & Bw1 $(18-44 \mathrm{~cm})$ & 2.0 & 3.10 & 0.4070 \\
3. & Bw2 $(44-65 \mathrm{~cm})$ & 3.0 & 2.94 & 0.3090 \\
4. & Bw3 $(65-75 \mathrm{~cm})$ & 3.0 & 3.04 & 0.4045 \\
5. & Bw4 $(75-85 \mathrm{~cm})$ & 8.0 & 2.98 & 0.9045 \\
6. & Bw5 $(85-108 \mathrm{~cm})$ & 8.0 & 2.70 & 0.4070 \\
7. & Ap $(0-20 \mathrm{~cm})$ & 7.5 & 1.75 & 0.5215 \\
8. & AB $(20-40 \mathrm{~cm})$ & 7.0 & 1.55 & 0.5090 \\
9. & BA $(40-60 \mathrm{~cm})$ & 6.5 & 1.56 & 0.2260 \\
10. & Bw1 $(60-88 \mathrm{~cm})$ & 6.0 & 1.65 & 0.3165 \\
11. & Bw2 $(88-120 \mathrm{~cm})$ & 7.0 & 3.06 & 0.2285 \\
12. & Bw3 $(120-150 \mathrm{~cm})$ & 8.0 & 3.10 & 0.3120 \\
13. & Ap $(0-30 \mathrm{~cm})$ & 4.0 & 2.93 & 0.3045 \\
14. & Bw $(30-40 \mathrm{~cm})$ & 5.5 & 3.11 & 0.2020 \\
15. & Bt1 $(40-60 \mathrm{~cm})$ & 5.5 & 3.10 & 0.2265 \\
16. & Bt2C $(60-150 \mathrm{~cm})$ & 9.0 & 3.10 & 0.2070 \\
\hline & & & &
\end{tabular}

evidences speaks about the negative correlation between hot water-soluble boron and calcareous nature of the soil.

\section{Land suitability and land capability classification}

Based on soil analytical properties, all the three pedons are classified into IIIew wherein limitation exists due to top soil erosion and high water table. Considering the suitability of the soil (Sys, 1985), for the cultivation of coconut and coconut-based intercrops, the soils are highly suitable (S1) for the cultivation of coconut and moderately suitable (S2) for the cultivation of cocoa and marginally suitable (S3) for the cultivation of pepper.

\section{Soil constraints and recommendation}

The $\mathrm{pH}$ of the soil samples across A Block is slightly alkaline. Application of gypsum may be followed for the groundnut growing soils of $A$ Block. In B Block, the sporadic occurrence of calcareous patches was witnessed. Application of green manures may be adopted to tone down the harmful effects of $\mathrm{CaCO}_{3}$ on crop productivity. In the highly calcareous $\mathrm{C}$ Block of the farm, crops sensitive to high $\mathrm{CaCO}_{3}$ may be avoided.

The soils are prone to top soil erosion and leaching owing to the sandy texture of the soil. In the surface soil, about 84 per cent of the soil samples recorded low status of $\mathrm{KMnO}_{4}-\mathrm{N}$, and in the subsurface, about 92 per cent of the soil samples had low status (Fig. 3). This may be attributed to the leaching losses of nutrients and the high water table which warrants split application of nutrients and use of slow-release nitrogenous fertilizers. Available phosphorus status was low to medium in the surface soils of the farm which may be attributed to the fixation of phosphorus as calcium phosphate. Scrupulous application of organic manures and biofertilizers might enhance the phosphorus availability in the soil. Across the farm, about 34 per cent of the soil samples were low, 53 per cent were medium, and 12 per cent were high in exchangeable potassium content. The station is located in the region, which is highly weathered and rich in kaolinitic clay mineral, which has hardly any binding site for potassium (Venkatesan and Murugesan, 2006).

Moreover, the prevalence of eriophyid mite is alarming in the coconut plantations of the region.
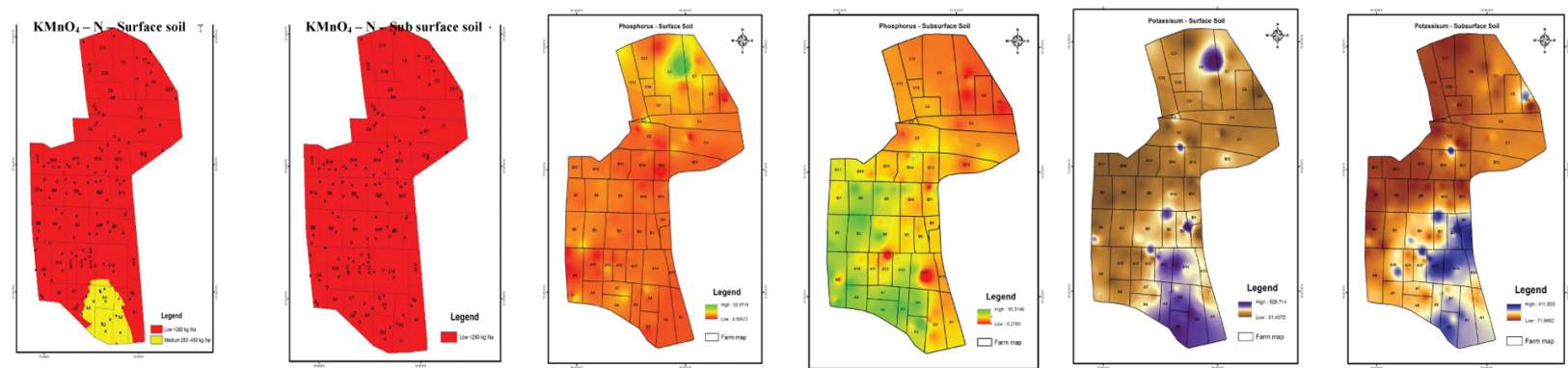

Fig. 3. Spatial variability of soil macronutrients at CRS, Aliyarnagar 
Table 9. Water quality of different irrigation sources of CRS, Aliyar Nagar

\begin{tabular}{|c|c|c|c|}
\hline $\begin{array}{l}\text { Sl. } \\
\text { No. }\end{array}$ & Parameter & Canal & $\begin{array}{l}\text { Open well } \\
\text { - A Block } \\
\end{array}$ \\
\hline 1. & $\mathrm{pH}$ & 6.90 & 7.58 \\
\hline 2. & Electrical conductivity $\left(\mathrm{dS} \mathrm{m}^{-1}\right)$ & 0.08 & 0.44 \\
\hline 3. & Phosphorus (meq L-1) & 0.0253 & 0.0270 \\
\hline 4. & Potassium (meq L-1) & 0.0282 & 0.0487 \\
\hline 5. & Sodium (meq L-1) & 0.2565 & 0.3913 \\
\hline 6. & Calcium (meq L-1) & 0.0723 & 0.0114 \\
\hline 7. & Magnesium (meq L-1) & 0.0 & 4.4 \\
\hline 8. & Carbonate (meq L-1) & 0.0 & 0.0 \\
\hline 9. & Bicarbonate (meq L-1) & 2.4 & 6.0 \\
\hline 10. & $\mathrm{SO}_{4}-\mathrm{S}($ meq L-1) & 0.2147 & 0.2764 \\
\hline 11. & Boron (meq L-1) & 0.4137 & 0.4188 \\
\hline \multirow[t]{2}{*}{12.} & Chloride (meq L ${ }^{-1}$ ) & 0.0016 & 0.0021 \\
\hline & Derived parameters & & \\
\hline 13. & Total dissolved solids (ppm) & 51.2 & 281.6 \\
\hline 14. & Sodium adsorption ratio & 1.35 & 0.2635 \\
\hline 15. & $\begin{array}{l}\text { Residual sodium carbonate } \\
\left(m e q L^{-1}\right)\end{array}$ & 2.3277 & 1.5886 \\
\hline 16. & $\begin{array}{l}\text { Residual sodium bicarbonate } \\
\left.\text { (meq L } \mathrm{L}^{-1}\right)\end{array}$ & 2.3277 & 5.9886 \\
\hline 17. & Soluble sodium percentage & 78.0 & 8.15 \\
\hline 18. & Permeability index & 5.4917 & 0.5915 \\
\hline 19. & Magnesium adsorption ratio & 0.0 & 0.9974 \\
\hline 20. & Potential salinity (meq L ${ }^{-1}$ ) & 0.1089 & 0.1403 \\
\hline 21. & Sodium ratio & 3.5477 & 0.0887 \\
\hline 22. & Sodium to calcium activity ratio & 0.9539 & 3.6649 \\
\hline 23. & Puri's salt index & -19.9676 & -6.389 \\
\hline
\end{tabular}

Hence the application of an enhanced dose of potassic fertilizers and split application of potassium can help in protecting the crops from $\mathrm{K}$ deficiencies. About 33 per cent of the soil samples analysed had a low status of organic carbon. Application of organic manures and biomass recycling of coconut fronds and wastes may be practised to step up the organic carbon content of the soil across the farm.

Rock outcrops are commonly witnessed in the C Block of the farm. Those areas may be used for pasture development, and split application of fertilizers may be practised in the adjacent areas owing to the shallow depth of the soil. In the zones where seepage problems persist, appropriate engineering measures like digging of trenches may be adopted.

\section{Quality of irrigation water}

Water samples were collected from two irrigation sources of the farm viz., canal and open well in A Block. Quality parameters of the irrigation sources are furnished in Table 9.

Irrespective of the sources of irrigation, $\mathrm{pH}$ of the water samples were neutral in reaction whilst electrical conductivity was non-saline. Total dissolved solids were non-detrimental in both the sources. However, as the soils are sandy in texture, salt accumulation is not a major concern on the farm. A high concentration of sodium is undesirable in water because sodium adsorbs onto the soil cation exchange sites, causing soil aggregates to break down (deflocculation) sealing the pores of the soil and making it impervious to water flow. The tendency of sodium to increase in proportion on the cation exchange sites at the expense of other types of cations is estimated by the ratio called sodium adsorption ratio (SAR). Although SAR is not a constraint in all the irrigation sources, residual sodium carbonate and sodium ratio were high in canal water and water collected from an open well. Residual sodium bicarbonate was high in open well while it was within the prescribed limits in the canal water depicting that open well water is bicarbonate rich.

Soluble sodium percentage, permeability index, magnesium adsorption ratio and Puri's salt index of all the sources do not pose a threat for irrigation. As potential salinity of all the sources of irrigation was $<1 \mathrm{meq} \mathrm{L}^{-1}$, they do not pose any restriction for irrigation. As far as sodium to calcium activity ratio is concerned, both the sources are well within the permissible limits for irrigation. Individual ion toxicities viz., chloride, boron and sulphur were not observed in all the sources. Thus it can be concluded that canal water is sodium dominant soft water while the other source is magnesium bicarbonate rich hard water.

\section{Conclusion}

Although Coconut Research Station, Aliyarnagar is endowed with the rich potential of irrigation water, soil-related constraints viz., widely prevalent deficiencies of macronutrients viz., 
$\mathrm{KMnO}_{4}-\mathrm{N}$, Olsen-P, $\mathrm{NNNH}_{4} \mathrm{OAc}-\mathrm{K}$ exist, warranting split application of fertilizers to prevent sand drown effect of the nutrients. Continuous application of organic manures is imperative for improving the soil organic matter content and to enhance the fertilizer use efficiency in all the blocks of the farm. The soils are highly prone to top soil erosion and seepage problems. Appropriate engineering measures such as providing trenches are essential to avoid temporary waterlogging. Rock outcrops and calcareous patches sporadically occur in the farm and nutrient management should be altered accordingly to reap better yields. Thus an appraisal of potentialities and problems of a centre of agro-technology generation like Coconut Research Station, Aliyarnagar is purposeful in the context of improving the system productivity, increasing the economic returns of the farmers, without deteriorating the natural resources.

\section{References}

Black, C.A. (Ed.). 1965. Methods of Soil Analysis. Part I. American Society Madison, Wisconsis, USA.

Bhattacharya, T., Dipak, S and Pal, D.K. 2009. Soil Survey Manual. NBSS \& LUP, Publication No. 146:1-100.

Yunan, D., Xianliang, Q. and Xiaochen, W. 2018. Study on cation exchange capacity of Agricultural soils. IOP Conf. series. Materials Science and Engineering 392.042039.

Gaston, L.A., Locke, M.A., Zablotowicz, R.M. and Reddy, K.N. 2001. Spatial variability of soil properties and weed populations in the Mississippi Delta. Soil Science Society of America Journal 65: 449-459.

Gooverts, P. 1998. Geostatistical tools for characterizing the spatial variability of microbiological and physico- chemical soil properties. Biology and Fertility of Soils 27(4): 315-334.

Gorai, T., Ahmed, N., Mahapatra, S.K., Datta, S.C., Singh, R.D. and Sharma, R.K. 2013. Effect of topography and vegetation on soil development in Kumaon hills of North Western Himalayas. Journal of Soil and Water Conservation 12: 269-276.

Mahapatra, S.K., Jagat Ram, Singh, S.P. and Dhankar, R.P. 2005. Soil resource inventory of warm humid Kumaon Himalayas for sustainable land use. Journal of the Indian Society of Soil Science 53: 390-393.

Rockstrom, J., Barron, J., Brouwer, J., Galle S. and de Rouw, A. 1999. On-farm spatial and temporal variability of soil and water in pearl millet cultivation. Soil Science Society of America Journal 63: 1308-1319.

Sarma, V.A.K., Krishnan, P. and Budhihal, S.L., 1987. Laboratory Methods. NBSS Pub. 14, Technical Bulletin, National Bureau of Soil Survey and Land Use Planning, Nagpur, p. 49.

Selvamani, V. and Duraisami, V.P. 2014. Identifying and mapping soil fertility constraints for coconut in Coimbatore and Tiruppur districts of Tamil Nadu State, India. Journal of Plantation Crops 42(3): 348-357.

Sudhalakshmi, C., Kumaraperumal, R., Arulmozhiselvan K. and Shoba, N. 2017. Exploring the spatial variability in soil macronutrients (NPK) of Coconut Research Station, Aliyarnagar employing geospatial techniques. Madras Agricultural Journal 104(1-3): 49-53.

Sys, C. 1985. Land Evaluation. Part II. Agriclas, Publication 7, Ghent, Belgium. pp.143-157.

Venkatesan, S. and Murugesan, S. 2006. Influence of tea cultivation on soil characteristics with special reference to potassium. International Journal of Soil Science 1: 58-63. 